\title{
Vulnerability assessment due to the climate change in Vinh Long province
}

\author{
Le Ngoc Tuan ${ }^{1, *}$, Nguyen Van Bang ${ }^{2}$
}

\begin{abstract}
This work aimed to assess the vulnerability to the climate change (CC) in Vinh Long province till 2020. Inundation, saltwater intrusion (SI), drought, riverbank landslide, storm, temperature and precipitation were taken into consideration. In addition to the socialogical investigation, risk assessment matrix, adaptive capacity assessment methods, etc. the vulnerability to CC was evaluated via index method. Results showed that among 8 districts in the province, Long Ho, Vung Liem, Vinh Long city, and Tam Binh were the most vulnerable. Besides, sectors interested in the relationship to $\mathrm{CC}$ include agriculture, infrastructure, and landuse. Indicated vulnerable sectors and areas in the province were important factor for planning suitable coping measures, especially in the context of $\mathrm{CC}$ seriously increasing.
\end{abstract}

Keywords - climate change, adaptive capacity, risk, vulnerability

\section{INTRODUCTION}

$\mathrm{G}$ lobal climate change (CC) heavily impacts people life [1]. In VietNam, within 50 recent years, the increase in average temperature (by 0.7 ${ }^{\circ} \mathrm{C}$ ), sea level rise $(20 \mathrm{~cm})$, and severe weather phenomena are impacting increasingly serious. By the end of the $21^{\text {st }}$ century, the average temperature and sea level will increase from 2.5 to $3.7^{\circ} \mathrm{C}$ and $78-95 \mathrm{~cm}$, respectively [2].

Vulnerability to climate change is the degree to which geophysical, biological and socio-economic systems are susceptible to, and unable to cope with, adverse impacts of climate change. Vulnerability assessment is very important to

Received 16-12-2017; Accepted 28-02-2018; Published 20-11-2018

Le Ngoc Tuan ${ }^{1, *}$, Nguyen Van Bang ${ }^{2}-{ }^{1}$ University of Science, VNU-HCM; ${ }^{2}$ Institute of Meteorology Hydrology Oceanology and Environment

*Email : Intuan@hcmus.edu.vn determine defective links of a system, and then to establish respective response measures [1, 3]. There were many researches on assessing vulnerability due to $\mathrm{CC}$ to social and economic sectors by many different methods. A method of NOAA - USA mainly focussed on assessing disaster risks impacting infrastructure, economy, society, and environment, etc. MASSCOTE method of $F A O$ was used to assess the vulnerability of irrigation sector [4]. Besides, vulnerability is aslo assessed by index method, such as Flood Vulnerability Index (FVI) including adaptive module, social vulnerable module, and damage module [5]; Social and Infrastructure Flood Vulnerability Index (SIFVI) [6]; Vulnerability Index due to flood -calculated via flood frequency, exposure and serious level (not including social impacts due to flood) [7]; Vulnerability index to $\mathrm{CC}$ of poor coastal communities [8]; or Vulnerability index calculated via exposure and resistance [9], etc. In VietNam, many studies on vulnerability of social economic sectors have also been performed with different approaches [10,11]. In general, vulnerability has been assessed via three main aspects: exposure, sensitivity (or risk level), and adaptive capacity of a system.

Vinh Long province is located in the MeKong Delta where could be the most flooded in the context of sea level rise [2]. The terrain is relatively low as compared to the sea level, consequently, the north of this area is usually inundated by flood; the area between the the National Rout 1 and Mang Thit river is often inundated by both flood and tide; the south of Mang Thit district is mostly flooded by tide. Flooding time is about 2 to 4 months. Besides, SI is also the concern when maximum salinities in main rivers of Vinh Long province have increased over the years (2007-2016) and increasingly enter 
the inland (1\%o salinity boundary). In 2016, higher salinities were recorded in Hau River, Vung Liem, Mang Thit, and Tra On districts (2\%o salinity boundary); moreover, salinity boundary of $8 \%$ was appeared in Vung Liem district. In addition, natuaral disasters such as riverbank landslide, storm, drought, etc. have also happened quite frequently, thus seriously impacted lives and production of the local, especially in the context of CC [12].

Therefore, this research aimed at assessing vulnerability due to $\mathrm{CC}$ in Vinh Long province to 2020, indicating the areas and sectors needing taking into account according to main impacts of $\mathrm{CC}$, providing basis for planning adaptive measures, contributing to reduce damages by $\mathrm{CC}$, ensuring the sustainable development goals of the local.

\section{METHODS}

Vulnerability to $\mathrm{CC}$ of the main sectors were assessed (land use -SDD, mineral resources TNKS, agriculture -NN, aquaculture -TS, industry -CN, transportation -GT, construction -XD, services - travel -DV-DL, society -XH) in all 8 districts/city in Vinh Long province (Vinh Long city, Vung Liem, Mang Thit, Tra On, Tam Binh, Binh Tan, Binh Minh, and Long Ho districts).

\section{Data collection and processing method}

Related data and documents were collected at the agencies and departments in Vinh Long province to assess impacts, risk level, adaptive capacity, and vulnerability to $\mathrm{CC}$, and then processed by Microsoft Excel software. Besides, this research aimed at assessing the vulnerability to $\mathrm{CC}$, so simulation results of $\mathrm{CC}$ scenarios (by SIMCLIM software, according to AR4 record of IPCC [1]), risks of SI and inundation by tide in the context of $\mathrm{CC}$ were inherited. Our previous research showed that in 2020, according to the average emission scenario (B2), temperature and precipitation in Vinh Long province would be $27.64{ }^{\circ} \mathrm{C}$ and $1,491.80 \mathrm{~mm}$, respectively. For water level, it would increase about $9 \mathrm{~cm}$ as compared to that in the reference period (19801999).

\section{Sociological survey method}

This method was used to assess the awareness about CC, adaptive capacity to $\mathrm{CC}$ of local managers, management agencies, and communities.

Communities: A representative survey was conducted in urban (Vinh Long city) and rural areas (Tam Binh, Tra On, and Vung Liem districts) which are also significantly affected by saltwater intrusion and inundation. 600 questionnaires were collected (150 questionaires/area with a reliablity of $92 \%$ ).

Managers and management agencies: The surveys were conducted in 22 agencies, including: The People's Committees of 08 districts/city in Vinh Long province (as mentioned), 12 departments (Department of Natural Resources and Environment -DONRE, Department of Agriculture and Rural Development -DOARD, Department of Industry and Trade -DOIT, Department of Transport -DOT, Department of Construction -DOC, Department of Health -DOH, Department of Science and Technology -DOST, Department of Planning and Investment -DOPI, Department of Culture, Sports and Tourism DOCST, Department of Education and Training DOET, The Steering committee for Flood and Storm Control -SCFSC, The Industrial zones authority -IZA) and 02 other related units (VinhLong Water Supply Company and VinhLong Power Company). 250 questionnaires were collected.

\section{Vulnerability assessment method}

According to the concept of vulnerability of IPCC [1], in this work, the vulnerability to CC (V) was calculated by formula: $V=1 / 2(R+5-A C)$; in which, evaluated scores were standardized by the scale of $0-5$; $\mathrm{R}$ was risk level due to $\mathrm{CC}$; $\mathrm{AC}$ was adaptive capacity. The vulnerability to $\mathrm{CC}$ in each local was assessed according to the following scale as presented in Table 1.

\section{Assessing risks due to $\mathrm{CC}$}

This method was used to assess risks due to $\mathrm{CC}$ (RR) as a basis to evaluate the vulnerability to CC as mentioned, in which possibility that social and economic aspects would be damaged was considered [11]. Related CC factors taken into account were flood, SI, drought, temperature, precipiattion, landslide, and storm. Depending on the occurrence possibility and related damages, the risk level due to each $\mathrm{CC}$ factor in each local was assessed according to the scale in Table 1. 
Table 1. Assessing sacle of the vulnerability (or risk) to CC

\begin{tabular}{|c|c|c|c|c|}
\hline $\mathbf{0}<\mathbf{V}($ or $\mathbf{R R}) \leq \mathbf{1}$ & $\mathbf{1}<\mathbf{V}($ or $\mathbf{R R}) \leq \mathbf{2}$ & $\mathbf{2}<\mathbf{V}($ or $\mathbf{R R}) \leq \mathbf{3}$ & $\mathbf{3}<\mathbf{V}($ or $\mathbf{R R}) \leq \mathbf{4}$ & $\mathbf{4}<\mathbf{V}($ or $\mathbf{R R}) \leq \mathbf{5}$ \\
\hline Very low & Low & Average & High & Very high \\
\hline
\end{tabular}

Risk level due to $\mathrm{CC}$ of each sector in each local was calculated as follows:

- Determining the risk level (of each sector) to each CC factor (risk component).

- Determining the weight of each CC factor in relation to the considered sector by Expert method.

- Calculating the integrated risk level to CC (based on values of risk component and corresponding weight)

\section{Assessing adaptive capacity to CC}

Adaptive capacity was the ability or potential of a system to respond successfully to climate variability and change, and included adjustments in both behaviour and in resources and technologies [11]. Adaptive capacity of each local (used to calculate $\mathrm{V}$ index as mentioned, and then indicate defective links of the system) was assessed by indicators as Table 2. Assessing scale of AC was showed in Table 3.

Table 2. Assessing indicators of adaptive capacity to CC

\begin{tabular}{|c|c|c|c|}
\hline Object & Group & Component & Code \\
\hline \multirow{12}{*}{$\begin{array}{c}(1) \\
\text { Community }\end{array}$} & \multirow{3}{*}{$\begin{array}{l}\text { People } \\
{[13,14]}\end{array}$} & Awareness of CC [15] & $\mathrm{CN} 1$ \\
\hline & & $\begin{array}{l}\text { The percentage of people participating in activities responding to CC } \\
\text { [16] }\end{array}$ & $\mathrm{CN} 2$ \\
\hline & & $\begin{array}{l}\text { The percentage of people living in places affected by } \mathrm{CC} \text { and haing } \\
\text { adaptation experience [17] }\end{array}$ & $\mathrm{CN} 3$ \\
\hline & \multirow{2}{*}{$\begin{array}{l}\text { Finance } \\
{[13,14]}\end{array}$} & Per capita income [14] & TC1 \\
\hline & & Support of governments in recovery from natural disasters [18] & TC2 \\
\hline & \multirow{3}{*}{$\begin{array}{l}\text { Facilities } \\
(\text { CSVC) } \\
{[13,14]}\end{array}$} & Transportation [19] & VC1 \\
\hline & & Irrigation system [19] & $\mathrm{VC} 2$ \\
\hline & & $\begin{array}{l}\text { Existing facilities: housing structure; percentage of people } \\
\text { using national electricity and clean water supply network; ability of } \\
\text { accessing information, etc. [20] }\end{array}$ & VC3 \\
\hline & \multirow{4}{*}{$\begin{array}{l}\text { Society } \\
{[13,14]}\end{array}$} & Percentage of teacher-to-pupil [13] & XH1 \\
\hline & & Percentage of medical staff-to-population [13] & $\mathrm{XH} 2$ \\
\hline & & Percentage of employee [16] & $\mathrm{XH} 3$ \\
\hline & & Percentage of people being communicated about CC [15] & $\mathrm{XH} 4$ \\
\hline \multirow{6}{*}{$\begin{array}{c}(2) \\
\text { Management } \\
\text { agencies (The } \\
\text { departments } \\
\text { managing } \\
\text { economic } \\
\text { sectors) }\end{array}$} & \multirow{3}{*}{$\begin{array}{l}\text { Organization } \\
{[13,14]}\end{array}$} & $\begin{array}{l}\begin{array}{l}\text { Organizational structure, number of managers working on } \mathrm{CC} \\
\text { management (or related tasks) [16] }\end{array} \\
\end{array}$ & TC1 \\
\hline & & Awareness of CC of local managers [13] & TC2 \\
\hline & & The policies related to CC responses [21] & TC3 \\
\hline & $\begin{array}{c}\text { Coordination } \\
\text { mechanism }\end{array}$ & Cooperative relationship in CC response missions [22] & $\mathrm{CCPH}$ \\
\hline & $\begin{array}{c}\text { Facilities } \\
{[13,14]}\end{array}$ & $\begin{array}{l}\text { Serving CC responses in general and coping with incidents due to CC } \\
\text { and natural disaster in particular [22] }\end{array}$ & CSVC \\
\hline & Finance & $\begin{array}{l}\text { Active and/or fixed finance sources for CC response activities as well as } \\
\text { finance invested through programs and projects related to CC }[16,23]\end{array}$ & NS \\
\hline $\begin{array}{c}\text { (3) } \\
\text { Management } \\
\text { agencies }\end{array}$ & \multicolumn{2}{|c|}{$\begin{array}{l}\text { (The People's Committees of districts) } \\
\text { Similar to group (2) }\end{array}$} & \\
\hline
\end{tabular}

Table 3. Assessing scale of adaptive capacity to CC

\begin{tabular}{|c|l|}
\hline Scale & \multicolumn{1}{|c|}{ Description } \\
\hline $0<\mathrm{AC} \leq 1.5$ & Poor $\mathrm{AC}$, many shortcomings, affecting many factors \\
\hline $1.5<\mathrm{AC} \leq 2.5$ & Medium $\mathrm{AC}$, many shortcomings but could be overcome \\
\hline $2.5<\mathrm{AC} \leq 3.5$ & Enough $\mathrm{AC}$, might have some shortcomings but harmless \\
\hline $3.5<\mathrm{AC} \leq 4.5$ & Good $\mathrm{AC}$, might have few shortcomings but harmless \\
\hline $4.5<\mathrm{AC} \leq 5$ & Very good $\mathrm{AC}$, no shortcomings \\
\hline
\end{tabular}


Weights among indicators (components or groups) were equal, thereby, $\mathrm{AC}_{\text {group }}$ index was calculated by average of $\mathrm{AC}_{\text {component }}$ index; $\mathrm{AC}_{\text {object }}$ index was calculated by average of $\mathrm{AC}_{\text {group }}$.

$A C$ index of each sector $\left(A C_{\text {sector }}\right)$ in each local was integrating calculated by $\mathrm{AC}_{\text {object }}$ indices, including communities, local management agencies, and departments managing related sectors*, with respectively weights of 0.3:0.3:0.4. *Land use and mineral resource sectors were assessed in relationship with DONRE; agricultura and aquaculture -DOARD; industry -DOIT; service and travel -DOCST; transportation -DOT; construction -DOC; other sectors -DOH, DOST, DOPI, DOET, SCFSC.

$A C$ of each local $\left(A C_{\text {local }}\right)$ was calculated by average of $\mathrm{AC}_{\text {sector }}$ indices of that local.

\section{Expert method}

This method was used to determine weights of $\mathrm{CC}$ factors in relationship to each economic social sector based on 30 experts' opinions: (i) Ranking importances of CC factors to landuse sector (The more important the factor is, the higher the ranking score will be); (ii) Determining ranking score of each factor $\left(\mathrm{m}_{\mathrm{i}}\right): m_{i}=$ Total score of factor $i$ / Number of questionaires; (iii) Calculating the intermediate weight of each factor $\left(\mathrm{w}_{\mathrm{i}}^{\prime}\right)$ :

+ Accepting that minimum

$\mathrm{m}_{\mathrm{i}}$ has $\mathrm{w}_{\mathrm{i}}{ }^{\prime}=1.0$

+ Calculating $\mathrm{W}_{\mathrm{i}}^{\prime}$ of other factors by formula:

$$
\begin{aligned}
& w_{i}{ }^{\prime}=\frac{m_{i(\min )}}{m_{i}} \\
& w_{i}=\frac{w_{i}{ }^{\prime}}{\sum_{1}^{n} w_{i}{ }^{\prime}}
\end{aligned}
$$

$$
\begin{aligned}
& + \text { Calculating final weight } \\
& \text { of each factor }\left(\mathrm{w}_{\mathrm{i}}\right) \text { : }
\end{aligned}
$$

\section{RESULTS AND DISCUSSION}

\section{Adapative Capacity to CC}

\section{Management agency group}

AC index of the management agency group was presented in Table 4.

Regarding district management agencies: the average AC index was enough (2.9 point), ranging from 2.0 to 3.4 among investigated areas, in which, VinhLong city and TraOn district had the highest AC. Conversely, TamBinh had the lowest $\mathrm{AC}$ index in the province (2.0 point) because of limitations in organizational structure and financial capacity leading to the reduction in AC to $\mathrm{CC}$. The former reason was also the limitation of all areas, so it needed overcoming in order to consolidate the system, contributing to improving the AC of the local.

For departments managing sectors: average AC index was 3.0, ranging from 2.4 to 3.6. DOARD had the highest AC index (3.6 point, good level) due to highlights of organizational structure, finance, coordination mechanisms to cope with CC. Regarding departments managing sectors less sensitive to CC (DOCST, DOH, DOET, etc), AC índices ranged from 2.4 to 3.5 (medium to enough level). The weaknesses of AC to CC mostly come from organizational structure and coordination mechanisms in CC

\begin{tabular}{|c|c|c|c|c|c|c|c|c|}
\hline & Organization & $\mathrm{TC} 1$ & $\mathrm{TC} 2$ & TC3 & $\mathrm{CCPH}$ & CSVC & NS & Average \\
\hline \multirow{12}{*}{$\begin{array}{l}\text { Departments } \\
\text { and agencies }\end{array}$} & DONRE $^{(*)}$ & 2 & 3 & 4 & 4 & Qualified & 3 & 3.3 \\
\hline & DOARD $^{(*)}$ & 4 & 4 & 3.5 & 4 & Qualified & 3 & 3.6 \\
\hline & $\mathrm{DOT}^{(*)}$ & 1 & 2 & 2 & 4 & Qualified & 4 & 3.2 \\
\hline & $\mathrm{DOC}^{(*)}$ & 1 & 2 & 3.5 & 3 & Qualified & 3 & 2.7 \\
\hline & DOCST & 3 & 4 & 3 & 2 & Qualified & 2 & 2.4 \\
\hline & DOIT & 3 & 3 & 3 & 3 & Qualified & 2 & 2.7 \\
\hline & DOST & 1 & 4 & 2.5 & 4 & Qualified & 4 & 3.5 \\
\hline & DOPI & 1 & 4 & 2 & 4 & Qualified & 4 & 3.4 \\
\hline & DOET & 1 & 3 & 2 & 3 & Qualified & 3 & 2.7 \\
\hline & $\mathrm{DOH}$ & 1 & 3 & 2 & 3 & Qualified & 3 & 2.7 \\
\hline & IZA & 3 & 4 & 3.5 & 3 & Qualified & 3 & 3.2 \\
\hline & Average & 1,9 & $\mathbf{3 , 3}$ & 2.8 & 3.4 & & 3.1 & 3.0 \\
\hline \multirow{2}{*}{$\begin{array}{l}\text { The People's } \\
\text { Committees of }\end{array}$} & VinhLong city & 3 & 3 & 4 & 4 & Qualified & 3 & 3.4 \\
\hline & BinhMinh & 3 & 2 & 3 & 2 & Qualified & 3 & 2.6 \\
\hline
\end{tabular}
responses, thereby needed concerning and improving.

Table 4. Assessment results of adaptive capacity of management agencies group in Vinh Long province 
CHUYÊN SAN KHOA HỌC TỰ NHIÊN, TậP 2, SỐ 5, 2018

\begin{tabular}{|l|l|c|c|c|c|c|c|c|}
\hline \multirow{4}{*}{ districts } & Long Ho & 2 & 2 & 3 & 2 & Qualified & 4 & 2.8 \\
\cline { 2 - 9 } & BinhTan & 4 & 3 & 2 & 2 & Qualified & 4 & 3.0 \\
\cline { 2 - 9 } & MangThit & 2 & 2 & 4 & 2 & Qualified & 4 & 2.9 \\
\cline { 2 - 9 } & TraOn & 2 & 4 & 4 & 3 & Qualified & 3 & 3.1 \\
\cline { 2 - 9 } & TamBinh & 1 & 3 & 2 & 2 & Qualified & 2 & 2.0 \\
\cline { 2 - 9 } & VungLiem & 2 & 4 & 2 & 3 & Qualified & 3 & 2.9 \\
\cline { 2 - 9 } & Average & $\mathbf{2 , 4}$ & $\mathbf{2 , 9}$ & $\mathbf{3}$ & $\mathbf{2 . 5}$ & & $\mathbf{3 . 3}$ & $\mathbf{2 . 9}$ \\
\hline
\end{tabular}

\section{Community group}

AC of community in Vinh Long Province was in medium level and not much different among local areas, ranging from 2.4 to 3.1 (highest in Vinh Long city) (Table 5). The aspects reducing $\mathrm{AC}$ of comnunity would be: low percentage of people participating in activities responding to $\mathrm{CC}$ (Tam Binh, Vung Liem, and Binh Tan districts),

(*) Managing sectors sensitive with impacts of CC

less effective support of irrigation system in production (Tam Binh, Tra On, Vung Liem, Mang Thit, and Binh Minh districts), and some social issues such as education, employment, etc. Improving these weaknesses is important tasks to improve $\mathrm{AC}$ of community and then to reduce vulnerability to $\mathrm{CC}$.

Table 5. Adaptive capacity of community in Vinh Long province

\begin{tabular}{|c|c|c|c|c|c|c|c|c|c|c|c|c|c|}
\hline \multirow{2}{*}{ District } & \multicolumn{3}{|c|}{ Human } & \multicolumn{2}{|c|}{ Finances } & \multicolumn{3}{|c|}{ Facilities } & \multicolumn{4}{|c|}{ Society } & \multirow{2}{*}{ Total } \\
\hline & $\mathrm{CN} 1$ & $\mathrm{CN} 2$ & $\mathrm{CN} 3$ & $\mathrm{TC} 1$ & $\mathrm{TC} 2$ & $\mathrm{VC} 1$ & $\mathrm{VC} 2$ & $\mathrm{VC} 3$ & XH1 & $\mathrm{XH} 2$ & XH3 & XH4 & \\
\hline Vinh Long city & 3 & 2 & 3 & 4 & 4 & 3,5 & 3 & 1,5 & 2 & 4 & 3 & 3 & 3.1 \\
\hline Tam Binh & 3 & 1 & 2 & 2.75 & 4 & 3.5 & 2 & 4 & 1 & 2 & 1 & 1 & 2.4 \\
\hline Tra On & 4 & 2 & 2 & 3 & 3 & 3.25 & 2 & 4.5 & 3 & 2 & 1 & 1 & 2.7 \\
\hline Vung Liem & 3 & 1 & 2 & 3 & 3 & 3.25 & 2 & 4.5 & 3 & 2 & 1 & 1 & 2.5 \\
\hline Mang Thit & 3 & 2 & 2 & 3 & 4 & 3.75 & 2 & 3.5 & 2 & 2 & 1 & 3 & 2.7 \\
\hline Binh Minh & 3 & 2 & 3 & 3.25 & 2 & 3.25 & 2 & 3 & 2 & 2 & 3 & 3 & 2.6 \\
\hline Long Ho & 3 & 2 & 2 & 2.75 & 3 & 3.25 & 3 & 3.5 & 2 & 1 & 4 & 3 & 2.7 \\
\hline Binh Tan & 4 & 1 & 2 & 3.75 & 3 & 3.75 & 3 & 4 & 1 & 1 & 4 & 1 & 2.8 \\
\hline
\end{tabular}

Table 6 presented AC index in each local area of Vinh Long province. In general, sectors and areas having enough adaptive capacity (according to AC assessment scale) would be agriculture, aquaculture, environmental resources, land use, Binh Tan district, and Vinh Long city.

Table 6. The AC index to $\mathrm{CC}$ in VinhLong province

\begin{tabular}{|l|c|c|c|c|c|c|c|c|c|c|}
\hline \multicolumn{1}{|c|}{ District } & SDD & TN - KS & NN & TS & CN & DV - DL & XH & GT & XD & Average \\
\hline Binh Minh & 3.03 & 3.03 & 3.14 & 3.14 & 2.76 & 2.67 & 2.93 & 2.98 & 2.78 & 2.94 \\
\hline Binh Tan & 3.29 & 3.29 & 3.41 & 3.41 & 3.03 & 2.94 & 3.20 & 3.25 & 3.05 & $\mathbf{3 . 2 1}$ \\
\hline Long Ho & 3.00 & 3.00 & 3.11 & 3.11 & 2.73 & 2.64 & 2.90 & 2.95 & 2.75 & 2.91 \\
\hline Mang Thit & 3.02 & 3.02 & 3.13 & 3.13 & 2.76 & 2.67 & 2.93 & 2.98 & 2.78 & 2.94 \\
\hline Tam Binh & 2.67 & 2.67 & 2.78 & 2.78 & 2.40 & 2.31 & 2.58 & 2.62 & 2.42 & 2.58 \\
\hline Tra On & 3.06 & 3.06 & 3.18 & 3.18 & 2.80 & 2.71 & 2.97 & 3.02 & 2.82 & 2.98 \\
\hline Vinh Long city & 3.29 & 3.29 & 3.40 & 3.40 & 3.02 & 2.94 & 3.20 & 3.25 & 3.05 & $\mathbf{3 . 2 0}$ \\
\hline Vung Liem & 2.95 & 2.95 & 3.06 & 3.06 & 2.69 & 2.60 & 2.86 & 2.91 & 2.71 & 2.87 \\
\hline Average & 3.04 & 3.04 & 3.15 & 3.15 & 2.77 & 2.68 & 2.95 & 2.99 & 2.79 & \\
\hline
\end{tabular}

\section{Risk level caused by CC}

Table 7 presented risk level due to $\mathrm{CC}$ of sectors in Vinh Long province. Accordingly, agriculture had the highest risk, especially in Vung Liem and Long Ho districts. In which, flood and SI were 2 main reasons. Besides, infrastructure, land use, environmental resource also had high risk with $\mathrm{CC}$ factors. The results also showed that Long Ho, Vung Liem, Tra On districts, and Vinh Long city need concerning with the specific sectors as follows: Long Ho - 
agriculture, industry, construction, and aquaculture; Vung Liem - agriculture, land use, and infrastructure; Tra On - infrastructure, environmental resource, and agriculture; VinhLong city - land use, transportation, and construction. These results are an important basis to consider and establish suitable solutions to cope with CC for each sector in each area in the local.

Table 7. Average risk level due to CC of sectors in Vinh Long province

\begin{tabular}{|c|c|c|c|c|c|c|c|c|c|c|}
\hline & & SDĐ & TNMT & $\mathrm{NN}$ & TS & $\mathrm{CN}$ & DVDL & $\mathrm{XH}$ & GT & $\mathrm{XD}$ \\
\hline \multirow{2}{*}{ Binh Minh } & Current & 1.2 & 0.9 & 0.86 & 0.77 & 1.12 & 0.8 & 1.01 & 1.21 & 1.38 \\
\hline & 2020 & 1.2 & 0.9 & 1.27 & 0.96 & 1.12 & 0.8 & 1.01 & 1.46 & 1.61 \\
\hline \multirow{2}{*}{ Binh Tan } & Current & 0.67 & 1.01 & 1.14 & 0.59 & 0.43 & 0.8 & 0.81 & 0.95 & 0.7 \\
\hline & 2020 & 0.67 & 1.01 & 1.55 & 0.59 & 0.43 & 0.8 & 0.81 & 0.95 & 0.93 \\
\hline \multirow{2}{*}{ Long Ho } & Current & 1.08 & 1.31 & 1.89 & 1.71 & 1.81 & 1.38 & 1 & 1.6 & 1.73 \\
\hline & 2020 & 1.27 & 1.31 & 1.89 & 1.94 & 1.81 & 1.57 & 1 & 1.6 & 1.96 \\
\hline \multirow{2}{*}{ Mang Thit } & Current & 1.05 & 1.1 & 1.52 & 1.41 & 1.16 & 0.71 & 0.86 & 1.17 & 1.14 \\
\hline & 2020 & 1.24 & 1.2 & 1.7 & 1.86 & 1.26 & 0.71 & 0.91 & 1.21 & 1.38 \\
\hline \multirow{2}{*}{ Tam Binh } & Current & 0.75 & 1.21 & 1.21 & 1.14 & 1.14 & 0.85 & 0.95 & 1.39 & 1.49 \\
\hline & 2020 & 0.75 & 1.21 & 1.62 & 1.14 & 1.37 & 0.85 & 0.95 & 1.39 & 1.72 \\
\hline \multirow{2}{*}{ Tra On } & Current & 1.18 & 1.52 & 1.52 & 1 & 1.14 & 0.85 & 1.3 & 1.56 & 1.76 \\
\hline & 2020 & 1.37 & 1.62 & 1.7 & 1.41 & 1.47 & 0.85 & 1.4 & 1.63 & 2.08 \\
\hline \multirow{2}{*}{$\begin{array}{c}\text { Vinh Long } \\
\text { city }\end{array}$} & Current & 1.68 & 1 & 1.21 & 0.77 & 0.68 & 1.18 & 1.19 & 1.48 & 1.39 \\
\hline & 2020 & 1.68 & 1 & 1.62 & 0.77 & 1.14 & 2.02 & 1.19 & 1.73 & 1.63 \\
\hline \multirow{2}{*}{ Vung Liem } & Current & 1.78 & 1.51 & 1.96 & 1.64 & 0.7 & 0.71 & 1.46 & 1.7 & 1.21 \\
\hline & 2020 & 1.78 & 1.51 & 1.96 & 1.86 & 0.8 & 0.77 & 1.51 & 1.73 & 1.61 \\
\hline
\end{tabular}

To calculate, assess, and also warn about the vulnerability to $\mathrm{CC}$ for sectors in Vinh Long province, this work used maximum risk level (detailed data was not showed). Accrodingly, the maximum risk level of sectors of (i) land use, (ii) environmental resource, (iii) agriculture, (iv) aquaculture, (v) industry, (vi) service and travel, (vii) society, (viii) transportation, and (ix) construction were ranged in 1-4, 2-4, 2-4, 1-4, 1$3,1-3,1-3,2-4$, and 1-4, respectively.

\section{Vulnerability assessment caused by $\mathrm{CC}$}

Based on the calculation of $\mathrm{AC}$ index and risk level due to $\mathrm{CC}$ factors, $\mathrm{V}$ the index was calculated and presented in Table 8.

Table 8. Vulnerability index to CC of sectors in Vinh Long province

\begin{tabular}{|c|c|c|c|c|c|c|c|c|c|c|}
\hline & & SDD & TNMT & $\mathrm{NN}$ & $\mathrm{TS}$ & $\mathrm{CN}$ & DVDL & $\mathrm{XH}$ & GT & $\mathrm{XD}$ \\
\hline \multirow{2}{*}{ Binh Minh } & Current & 2.49 & 1.99 & 1.93 & 1.43 & 2.62 & 1.67 & 2.04 & 2.01 & 2.61 \\
\hline & 2020 & 2.49 & 1.99 & 2.43 & 1.93 & 2.62 & 1.67 & 2.04 & 2.51 & 3.11 \\
\hline \multirow{2}{*}{ Binh Tan } & Current & 1.86 & 1.86 & 1.80 & 1.30 & 1.49 & 1.53 & 1.40 & 1.88 & 1.48 \\
\hline & 2020 & 1.86 & 1.86 & 2.30 & 1.30 & 1.49 & 1.53 & 1.40 & 1.88 & 1.98 \\
\hline \multirow{2}{*}{ Long Ho } & Current & 2.50 & 2.00 & 2.95 & 2.95 & 2.64 & 2.18 & 1.55 & 2.53 & 2.63 \\
\hline & 2020 & 2.50 & 2.00 & 2.95 & 2.95 & 2.64 & 2.68 & 1.55 & 2.53 & 2.63 \\
\hline \multirow{2}{*}{ Mang Thit } & Current & 1.99 & 1.99 & 2,44 & 1.94 & 2.12 & 1.67 & 1.54 & 2.01 & 2.11 \\
\hline & 2020 & 2.49 & 2.49 & 2.44 & 2.94 & 2.12 & 1.67 & 2.04 & 2.01 & 2.11 \\
\hline \multirow{2}{*}{ Tam Binh } & Current & 1.67 & 2.17 & 2.61 & 2.61 & 2.30 & 1.85 & 1.71 & 2.19 & 2.79 \\
\hline & 2020 & 1.67 & 2.17 & 2.61 & 2.61 & 2.80 & 1.85 & 1.71 & 2.19 & 2.79 \\
\hline \multirow{2}{*}{ Tra On } & Current & 1.97 & 1.97 & 2.41 & 1.41 & 2.10 & 1.65 & 2.02 & 2.49 & 2.59 \\
\hline & 2020 & 2.47 & 2.47 & 2.41 & 1.91 & 2.60 & 1.65 & 2.02 & 2.49 & 2.59 \\
\hline \multirow{2}{*}{$\begin{array}{l}\text { Vinh Long } \\
\text { city }\end{array}$} & Current & 2.86 & 1.86 & 2.30 & 1.30 & 1.99 & 2.03 & 1.90 & 2.38 & 2.48 \\
\hline & 2020 & 2.86 & 1.86 & 2.30 & 1.30 & 1.99 & 2.53 & 1.90 & 2.88 & 2.98 \\
\hline \multirow{2}{*}{ Vung Liem } & Current & 3.03 & 3.03 & 2.97 & 2.47 & 1.66 & 1.70 & 2.07 & 2.55 & 2.15 \\
\hline & 2020 & 3.03 & 3.03 & 2.97 & 2.97 & 2.16 & 1.70 & 2.57 & 2.55 & 2.65 \\
\hline
\end{tabular}




\section{Vulnerable areas to CC in Vinh Long province}

Table 8 and Fig. 1 showed Long Ho, Vung Liem, Vinh Long, and Tam Binh were the most



(A) vulnerable areas in Vinh Long province. Vulnerability index to $\mathrm{CC}$ of the local areas was detailed in Fig. $1 \mathrm{~b}$ by the scale $1.5-2.5$.

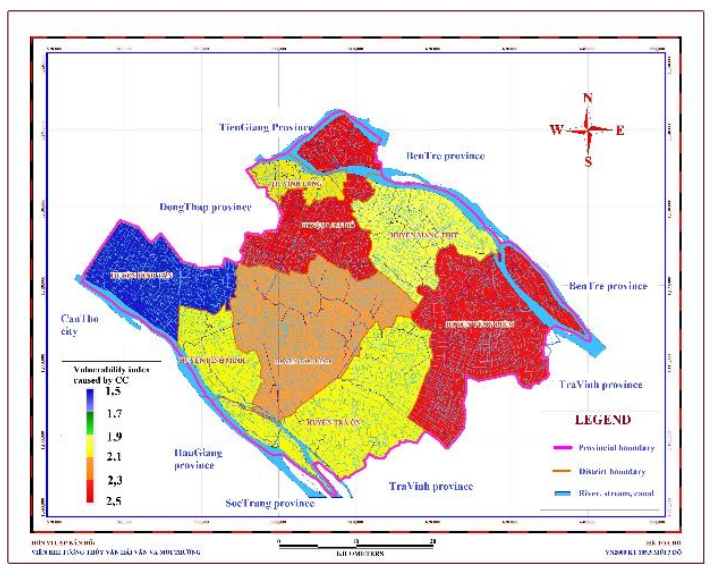

(B)

Fig. 1. Vulnerability to CC in VinhLong province: (A) Current status; (B) Detailed from current status

With specific characteristics of nature, economy, and society, each local area had different weaknesses in the relation to V to CC. In Long Ho, agriculture, aquaculture, industry, and infrastructure sectors needed concerning under CC impacts; land use, agricultura, and infrastructure for Vung Liem; land use and infrastructure for Vinh Long city; agriculture, aquaculture, and infrastructure for TamBinh. This was an important basis for proposing suitable solutions for corresponding sectors and areas to improve the effectiveness of activities coping to $\mathrm{CC}$ in the local.

\section{Vulnerable sectors to CC in Vinh Long province}

Agriculture, infrastructure (transportation and construction), and land use were the most vulnerable sectors to $\mathrm{CC}$ in Vinh Long province.

- Agriculture: was the decisive economic sector in Vinh Long province but the most vulnerable (Table 8). Average AC indices were higher than those of other sectors (Table 6), but just able to reduce partly the risk level. Therefore, the agriculture would be still the most concerned sector in the process of economic development in the local, especially in Vung Liem, Long Ho and Tam Binh districts.
Flood, temperature rise, and SI led to the increase in vulnerability of agriculture sector in the province.

+ The rate of flooded agricultural area and the related damages need concerning in Long Ho, Binh Minh, Binh Tan, and Vung Liem districts.

$+S I$ would impact agricultural sector in Vung Liem, Tra On, and Mang Thit districts, especially rice and a small part of crops.

+ Temperature had not yet significantly affected agricultural production but high temperature in dry season, many days per year with temperature higher than $35{ }^{\circ} \mathrm{C}$ (71 days in 2015), etc. would affect agricultural production areas, especially in Binh Tan, Binh Minh, and Long Ho districts.

- Infrastructure: (including 2 main sectors of transportation and construction) had concerned $\mathrm{V}$ index in Vinh Long province. Apart from relative high risk to $\mathrm{CC}$ impacts, $\mathrm{AC}$ of this sector was low, as follows:

+ Construction sector was affected by 3 main phenomena: flood, riverbank landslide, and storm. Flood affects infrastructure, housing structures, and engineering system, leading to the highest risk level to CC of Vinh Long city and Binh Minh district. Statistics in the past 5 years showed most of local areas had 
landslide, resulting in damages for dyke system, riverbank, canal, etc. Two most concerned areas were Tra On (15 landslide positions - about $1,367 \mathrm{~m}, 2015$ ) and LongHo (5 landslide positions - about $550 \mathrm{~m}, 2015$ ). Storm mostly affected housing structures (unroofed, collapse, breaking down, etc), especially in Tam Binh, Tra On, Long Ho, and Vung Liem districts.

$+\mathrm{AC}$ of the local agencies managing transportation and construction sectors were still low. It could be explained that these agencies were not responsible for CC issues, so organizational structure, human resources, accessing programs as well as information of $\mathrm{CC}$ needed more concerning.

- Land use: in the context of complex and increasingly negative change of climate, flood and SI were 2 main factors leading to significant impacts. As mentioned, $\mathrm{AC}$ index of this sector was relatively high $(\mathrm{AC}=3.04)$, runner up (after that of agriculture), therefore, vulnerability could be resulted from risks due to $\mathrm{CC}$.

+ SI impacted the most on land use in Vung Liem district, a part of Tra On and Mang Thit districts, accordingly impacted quality and function of land types, especially land for agricultural production.

+ Flood has impacted to a large area of Vinh Long province, especially in Vung Liem, Long Ho, Binh Minh districts, and Vinh Long city, etc.

+ Temperature, drought, precipitation, and landslide have caused insignificant vulnerability. However, unexpected evolutions and unpredictable impact intensity have posed requirements of monitoring changes of the weather, climate, and indicate timely warnings to effectively reduce related damages.

\section{CONCLUSION}

On the basis of assessment of AC and risk level, vulnerability to $\mathrm{CC}$ of the sectors and areas in Vinh Long province were assessed. The results showed that agriculture, infrastructure (transportation and construction), and land use were the most vulnerable sectors. Flood, SI, and increase in temperature would impact agriculture in Vinh Long province, especially in Vung Liem, Long Ho, and Tam Binh districts. Infrastructure in Vinh Long city and Binh Minh district had the highest $\mathrm{V}$ due to flood while Tam Binh, Tra On,
Long Ho and Vung Liem districts would have risks from storm. Regarding land use sector, SI would impact agricultural areas in Vung Liem, a part of Tra On and Mang Thit districts while flood would impact large area of Vinh Long province, especially in Vung Liem, Long Ho, Binh Minh districts, and Vinh Long city. The research also showed Long Ho, Vung Liem, Tam Binh districts, and Vinh Long city would be vulnerable areas due to $\mathrm{CC}$, needed planning coping solutions in order to reduce damages from $\mathrm{CC}$ and to ensure sustainable development goals of the province.

\section{REFERENCES}

[1] IPCC. 2007. IPCC Forth Assessment Report: Climate Change 2007 (AR4).

[2] Bộ Tài nguyên và Môi trường, Kịch bản Biến đổi khí hậu và nước biển dâng cho Việt Nam, Hà Nội, 2012.

[3] T.X. Hoang, L.N. Tuan, "Establishing Vulnerability Index to Saltwater instrution in the context of climate change", Ho Chi Minh City University of Natural Resources and Environment, Division of sea and island resources management, pp. 32-39, 2015.

[4] FAO, The state of food and agriculture, 2007, ftp://ftp.fao.org/docrep/fao/010/a1200e/a1200e00.pdf

[5] Z. Fang, A function-oriented methodology of flood vulnerability assessment, MSc thesis Water Resources Management, Civil Engineering, Delft University of Technology, 2009.

[6] P. Hayman, B. Alexander, "Wheat, wine and pie charts: advantages adn limits to using current variability to think about future change in South Australia"s climate", In: Jubb, I., Holper, P. and Cai, W. (Eds) Managing Climate Change: Papers from GREENHOUSE 2009 Conference. CSIRO Publishing, Melbourne, 2009.

[7] S. Karki, GIS based flood hazard mapping and vulnerability assessment of people due to climate change: case study from Kankai watershed, East Nepal,' report, National Adaptation Programme of Action (NAPA), Nepal, 2011

[8] I.O. Adelekan, Vulnerability of poor urban coastal communities to climate change in Lagos, Nigeria, 2007.

[9] F. Messner, V. Meyer, Flood damage, vulnerability and risk perception of challenges for food damage research. UFZ - Centre for Environment Research Leipzig - Halle, Member of the Dresden Flood Research Center (D-FRC), Dresden, Germany, 2006.

[10] N.T. Sơn, C.T. Văn, “Các phương pháp đánh giá tính dễ bị tổn thương - Lý luận và thực tiễn - Phần 1: Khả năng ứng dụng trong đánh giá tính dễ bị tổn thương lũ lụt ở Miền Trung Việt Nam", Tạp chí Khoa học Đại Học Quốc gia Hà Nội: Khoa hoc Tự nhiên và Công nghệ, vol. 28, no. 3S, pp.115-122, 2012.

[11] Viện Khoa học Khí tượng Thủy văn và Môi trường, Tài liệu huớng dần đánh giá tác động của $B Đ K H$ và xác định các giải pháp thích úng, Nhà xuất bản Tài nguyên Môi trường và Bản đồ Việt Nam, 2011.

[12] Sở NN\&PTNT tỉnh Vĩnh Long - Chi cục Thủy lợi, 2015, Sơ kết tình hình thực hiện công tác 6 tháng đầu năm và Kế hoạch công tác 6 tháng cuối năm 2015.

[13] Ellis, Rural Livelihoods and Diversity in Developing 
Countries, Oxford: Oxford University Press, 2000.

[14] B. Jacobs, R. Nelson, N. Kuruppu, P. Leith, "An adaptive capacity guide book: Assessing, building and evaluating the capacity of communities to adapt in a changing climate", Southern Slopes Climate Change Adaptation Research Partnership (SCARP), University of Technology Sydney and University of Tasmania. Hobart, Tasmania, 2015.

[15] Dala et al., Assessing Community Resilience to Climate Change, Cairns, Australia, 2012.

[16] Swanson \& et al, "Indicators of Adaptive Capacity to Climate Change for Agriculture in the Prairie Region of Canada", International Institute for Sustainable Development (IISD), Manitoba, Canada, vol. 17, 2007.

[17] L. Jones, et al., 2010. "Responding to a changing climate: Exploring how disaster risk reduction, social protection and livelihoods approaches promote features of adaptive capacity", ODI Working Paper 319. London: ODI (www.odi.org.uk/resources/ download/4790.pdf).

[18] John Wiley \& Sons, Community-based adaptation: enhancing community adaptive capacity in Druadrua Island, Fij00i, WIREs, vol. 1, pp. 751-763, 2010.

[19] B. Smit, O. Pilifosova, "Adaptation to climate change in the context of sustainable development and equity", in:
J.J. McCarty, O.F. Canzianni, N.A. Leary, D.J. Dokken, K.S. White (Eds), "Climate Change 2001: Impacts, Adaptation, and Vulnerability-Contribution of Working Group II to the Third Assessment Report of the Intergovernmental Panel on Climate Change, Cambridge, England, Cambridge University Press, 2001.

[20] E. Wall, K. Marzall, "Adaptive capacity for climate change in canadian rural communities", Local Environment, vol. 11, no. 4, pp. 373-397, August 2006.

[21] Adger et al, Assessing and Enhancing Adaptive Capacity, 2007 ,

http://www4.unfccc.int/nap/Country\%20Documents/Gen eral/apf\%20technical\%20paper07.pdf

[22] Ngân hàng phát triển châu Á (ADB), Nghiên cứu tác động của biến đổi khí hậu và đề xuất các giải pháp thích ứng ở đồng bằng sông Cửu Long - Phần A, 2001.

[23] John Wiley \& Sons, Community-based adaptation: enhancing community adaptive capacity in Druadrua Island, Fiji, WIREs, vol. 1, pp. 751-763, 2010. 


\title{
Đánh giá tính dễ bị tổn thương do biến đổi khí hậu tại tỉnh Vĩnh Long
}

\author{
Lê Ngọc Tuấn ${ }^{1}$, Nguyễn Văn Bằng ${ }^{2}$ \\ ${ }^{1}$ Trường Đại học Khoa học Tự nhiên, ĐHQG-HCM, \\ ${ }^{2}$ Viện Khoa học Khí Tượng Thủy Văn và Biến đổi khí hậu \\ Tác giả liên hệ: Intuan@hcmus.edu.vn
}

Ngày nhận bản thảo 16-12-2017; ngày chấp nhận đăng 28-02-2017; ngày đăng 20-11-2018

Tóm tắt-Nghiên cứu nhằm mục tiêu đánh giá tính dễ bị tổn thương (TDBTT) do biến đổi khí hậu (BĐKH) trên địa bàn tỉnh Vĩnh Long đến năm 2020. Các yếu tố được xem xét bao gồm ngập lụt, xâm nhập mặn, hạn hán, sạt lở, giông lốc, nhiệt độ và lượng mưa. Bên cạnh phương pháp điều tra xã hội học, ma trận đánh giá rủi ro, đánh giá năng lực thích ứng..., TDBTT do BĐKH được đánh giá thông qua phương pháp chỉ số. Kết quả cho thấy trong số 8 huyện thị tại địa phương, huyện Long Hồ, Vũng
Liêm, thành phố Vĩnh Long và huyện Tam Bình DBTT nhất do BĐKH. Bên cạnh đó, các lĩnh vực đáng quan tâm trong mối quan hệ với BĐKH bao gồm nông nghiệp, hạ tầng và sử dụng đất. Nghiên cứu chỉ ra các khu vực và lĩnh vực DBTT là cơ sở quan trọng cho việc hoạch định các giải pháp ứng phó với BĐKH tương thích tại địa phương.

Tù khóa-biến đổi khí hậu, khả năng thích ứng, rủi ro, tính dễ bị tổn thương. 